\title{
Audit Evidence and Financial Statement Quality in Government Owned Companies in Rivers State, Nigeria
}

\author{
ThankGod C. Agwor, and Paul Daziba Amangala
}

\begin{abstract}
The spate of Accounting scandals and Financial crisis in firms have undermined investors trust concerning financial statements, and as such has raised concerns and criticisms about the quality of financial statements. In order to regain investors' confidence on financial statements, the audit function lends credibility to the financial statements, particularly through obtaining audit evidence. Therefore, this study empirically investigated the extent of relationship between audit evidence and financial statement quality of Government owned companies in Rivers State. The survey research design was adopted. Questionnaires were administered to selected audit firms in Rivers State. Spearman's Rank Correlation analysis and ordinary least squares regression analysis were used to analyze the data. The study reveals significant relationship between audit evidence and financial statement quality of Government owned companies in Rivers State. Based on the findings, it was concluded that Audit evidence greatly improves financial statement quality of Government - owned companies in Rivers State. It was recommended that external auditor should always insist on the submission of a letter of representation from management before the end of an audit for purposes of improved reliability and relevance of financial statements.
\end{abstract}

Index Terms - Audit Evidence, Audit, Financial statement, Financial statement Quality.

\section{INTRODUCTION}

Kiabel opined that the need for an audit or auditing arose when the management of an enterprise was separated from the ownership [1]. With the separation and divorce of ownership from management, the only link between the two became the periodic reports on financial conditions and progress which are made by managers and directors to shareholders. Such financial statements are expected to be relied upon by investors, prospective investors, creditors, security analysts, Government regulatory agencies and others.

But there are potential problem associated with managements communication of financial information to these users. For example, such statements may contain errors, may not disclose fraud, the statements may be deliberately or inadvertently misleading or it may simply fail to disclose vital information. For these reasons, users of the statements may seek an independent assessment of the accounts presented by management. The audit function, thus, lends credibility to the financial statements. Credibility in its usage, means that the information can be believed, that is, it can be relied upon by outsiders such as

Published on December 28, 2020

ThankGod C. Agwor.

(corresponding e-mail: tagwor@yahoo.com)

Paul Daziba Amangala. creditors, government regulators and other interested third parties [2].

Because financial statement users were sometimes unable to take decisions on the true reflection of the underlying transactions stated in the financial reports and prepared in accordance with existing standard calls for the credibility of the financial statement [3]. Thus, the audit function, by adding credibility to financial statements, plays a special role of establishing and maintaining confidence in the investing public. Without such confidence, the whole basis of our capitalist system with its divorce of ownership from management in virtually all major enterprises would be destroyed [4]. The importance of the auditor's role is not in dispute. It is a matter of public interest that he should discharge the situation functions in the most effective manner possible. Moreover, Eke, opined that, the nature of some transactions is so complex such that only the expertise of professionals who understand the underlying economic substance of these transactions and can account for them properly may be required [5]. Users therefore rely on the auditor to have the requisite expertise to ensure the fair presentation of these complex transactions. Also, an audit is necessary in order to ensure that the financial statements confirm to the various requirements of the companies and Allied Matters Act and the many statements of Accounting Standards.

The audit function is also necessary as it encourages management to take appropriate action to correct errors that may have been noted, properly report any irregularities, and make necessary corrections to the financial statements. The independent opinion of the auditor thus plays a crucial role in economic decision making. The auditor should be an independent person who is appointed to investigate the organization, its records and the financial statement prepared from them and thus forms an opinion on the accuracy and correctness of the financial statements.

The essence of every audit is for the auditor to express an opinion on the credibility of the assertions made by the management about economic actions. For the auditor to express this opinion, he must collect evidence to verify that the figures and items recorded in the financial statement are real, true, and fair [1]. The evidence collected, thus, becomes the basis of reliance on the financial statements [1].

Kiabel defined audit evidence as the factual and collectable material which is capable of supporting the various accounting actions which are carried out by an organization when producing its accounting information and which forms the basis and justification of the auditors opinion on such information [1]. Without audit evidence, there is no basis for the audit work. The auditor ought to obtain and accumulate evidence to enable him form an 
opinion on the financial statements. The types of evidence obtained, and the criteria employed to evaluate evidence may vary from audit to audit, but all audits center on the process of obtaining and evaluating evidence. It includes accounting data and other corroborating information and facts available to the auditor which guides him in arriving at the conclusions on which his opinion is based. Without credible evidence, the auditor will have difficulty determining whether the financial statements show a true and fair view which necessitates the auditor considering the quality and quantity of evidence required to guide him or her in issuing opinion on the financial statements.

Financial statements are short documents that present the income information for a business at any given point in time. Financial statements provide financial data and information on the spot. Olagunju sees financial statement as a generic term for profit and loss account, balance sheets, cash flow statement, five year financial summary, value added statement, income and expenditure account, statement of accounting policy [6]. Financial statements are the end products of the accounting function. They provide readers with neat summaries of what has occurred during an accounting period. For accounting information to be useful, it has to be communicated to users of such information.

The external users find solace in the qualitative characteristics of the financial statement in making their economic decisions. This importance of financial statements to external users has been re-enforced by scandals in the International Financial Community which has raised many criticisms about the financial statement quality [19]. It is in line with this important view that those characteristics, relevance, and reliability should not be wishfully thrown away in preparation of financial statements. There is a growing interest in published accounts of companies in Nigeria and worldwide as a result of the former. Given this reality, the challenge is for auditors to obtain evidence in an attempt to gain and enhance the confidence and reliance of information users on financial statements which has been badly weakened overtime by the financial scandals mentioned earlier, and others too numerous to mention. This work is therefore aimed at determining the relationship between Audit Evidence and Financial Statement quality of Government owned companies in Rivers State.

The state of accounting scandals and financial crises in distinguished firms have undermined investors trust concerning the financial statements, and as such has raised concerns and criticisms about the quality of financial statements. As a result of the above, in order to regain investors' confidence in financial statements the audit function lends credibility to the financial statements, particularly through obtaining audit evidence. Therefore, this study has a general purpose which is to determine the relationship between audit evidence and financial statement quality of Government owned companies in Rivers State. This study has a general purpose which is to determine the relationship between Audit evidence and financial statement quality in Government owned companies in Rivers State.

A. Research Hypotheses

The following research hypotheses are made in order to provide answers to the questions posed.
$\mathrm{Ho}_{1}$ : There is no significant relationship between Accounting Records and reliability of Financial Statement of Government owned companies in Rivers State.

$\mathrm{Ho}_{2}$ : There is no significant relationship between Accounting Records and relevance of Financial Statements of Government owned companies in Rivers State.

$\mathrm{Ho}_{3}$ : There is no significant relationship between letter of representation and reliability of Financial Statement of Government owned companies in Rivers State.

$\mathrm{Ho}_{4}$ : There is no significant relationship between letter of representation and relevance of Financial statements of Government owned companies in Rivers State.

\section{LITERATURE REVIEW}

Recently, Joshi and Deshmukh investigated the reliability and validity of each type of audit evidence used by Bahraini auditors [20]. The results of the survey indicated in part of this study confirmed the Joshi and Deskmukh study findings that physical and documentary evidence was more dependable than other types of evidence which may be utilized such as oral evidence. Yet it was found in the interview process that within the Libyan context there is some questioning about the documentary evidence presented to the auditors. This study found that there are potential deviance issues which need further investigation for clarification. Joshi and Deshmukh advise that official documentation is difficult to manipulate yet the respondents and interviewees indicated that they have concerns over official documentation [20]. The discrepancies in the effectiveness and the efficiency of type of evidence to adopt or prioritized by auditors are things of concern to many auditors. The best form of evidence adopted by different auditors is a function of the experiences and the training received by the auditors.

Glover and Jardoh all drawn attention to the specific need to focus on audit evidence in particular relating to the quality of auditing report [21], [20]. The need becomes very necessary as there more indications that audit evidence are necessarily or unnecessarily embedded in the financial statement of the organizations. However, Rose and Rose advise that it is not always possible to determine the validity of specific information or its source [23]. This will further strengthen the quality of the financial report prepared by the organization

According to Janvrin [23] and ISA 500 (2010a), the auditors should assign greater persuasiveness to evidence from external parties than to evidence from internal parties [24]. This is because the external parties take more responsibilities and certain decision from the financial statements. Financial statement analysis further draws the attention of the external stake holders to the performance of the management team. Kizirian found that management integrity demonstrates incremental expounding power further than the risk of material misstatement for the expressiveness of audit evidence collected [25].

Understanding how articulacy and chronological presentation of audit evidence affects auditors' judgments is mostly important in conditions where there is conflicting 
(positive and negative) audit evidence of varying strengths. Studies have shown both that auditors place greater weight on negative evidence compared to positive evidence [26], [27], and that they are sensitive to source reliability [28], [29].

Prior literature indicated a strong support that individuals place more weight on evidence from a more reliable source when presented with conflicting evidence [31]. In auditing contexts, when presented with conflicting evidence, auditors are expected to place greater weight on audit evidence from a more reliable source. For this will further build the consistency in the progression of the reliability of the work of the auditors. In the views of Kaplan, it is expected that high audit evidence quality leads to high financial statement qualify which becomes an instrument for averting financial crisis and boosts stakeholder's confidence in financial statements [32].

Financial statement quality, therefore, relates to the accuracy with which reported financials of a firm reflects its operating performance and how useful they are in forecasting future cash flows [7]. Such qualities include, but are not limited to understandability, relevance, consistency, comparability, reliability, and objectivity, as identified by the American Accounting Association [7]. Financial statements provide information about the managements stewardship; the entity's assets, liabilities, equity, income and expenses (including gains and losses), contributions by and distributions to owners as well as cash flows [8]. This information is usually in the form of annual financial statements such as the statement of financial position, the income statement or statement of comprehensive income, statement of cash flows and statement of changes in equity as well as notes to the accounts [8].

Useful information has certain attributes and characteristics. According to the Financial Accounting Standard Board (FASB) in its Statements of Financial Accounting Concepts (SFAC) No. 2, there are two categories of identified attributes: namely Reliability and Relevance. Furthermore, Keiso Weygandt and Warfield, discusses qualitative characteristics of financial statement reports and end up classifying them into primary quality and secondary quality [9]. Primary quality includes reliability and relevance.

In recent past, there exist replicates of accounting scandals that engulfs front line companies such as Enron, Worldcom, Marconi, Parmalat, and many others. These series of accounting scandals have weakened investors' confidence on the management team and on financial statements. It has created some sense of damages in would be investors that rely so much on the reliability and validity of the quality of the financial reports to make certain decisions. These decisions, no matter how minutes they seem to be will be detrimental if it is taken base on poor financial statement quality.

Thus, the Extensive failure in the financial disclosure has generated the demand by investors, regulators, and other stakeholders for an enhancement of financial statement quality and the provision of necessary evidence to enhance and strengthen the reliance and relevance of the financial statements [15]. Hence, firms must prepare financial information with higher quality [17]. That is information disclosed must be relevant and reliable to assist users of financial statements in the decision making [18].

According to Obaidat and Elliot reliability quality of financial report builds assurance of the investors [34]. However, this does not exempt the possibility of future distortion of the efficiency of the financial statement after reliability check. Reliable information is having characteristics of neutrality and faithful representation of the financial information. Reliability information is also very much displaying the investible characteristics and the nature of the companies in terms of ethic development and social responsibility. The information further shows that the company or the organization is worth investing in. The main indicators of financial information or statement quality from the perspective of the developers of accounting standards are relevance and reliability which make information useful for decision makers [35]. However, other indicators developed by accounting standard professionals are in existence.

The investigation by Bushman and Smith indicated that lofty eminence financial statements increases investment competence [16]. Subsequent investigation by Biddle and Hillary gave preference to firm size as determined by the number of assets, firm life as determined by years of existence and type of industry as identified by listed companies on the stock exchange.

Noravesh carried out a study and concluded that financial reporting systems in firms hiring major trained accountants were significantly different from other firms [38]. The emphasis of this particular study was hinged on the training received by the accounting officers and the accounting personnel involved in handling the Accounting matter in the organization listed on the Tehran stock exchange.

In the study conducted by Lifeng, the concentration was on the examination of the impact of financial statement quality on investment costs, information uncertainty and agency [16]. In the study hypotheses were developed and further tested using the relevant statistical tools. However, in conclusion the study observed that high - quality financial statements reduced investment and agency costs. Therefore, we can propose that financial statement quality have a significant correlation with investment cost, information uncertainty and agency.

\section{METHODOLOGY}

This study adopted the survey design. The population chosen for the study comprises of selected public accountants or external auditors, particularly 152 external auditors from 38 different accounting firms in Rivers State, who are authorized to carryout audits of the financial statements of Government owned companies in Rivers State. Four questionnaires were administered to each of the 38 accounting firms in Rivers State.

The primary data obtained from the field will be analyzed using the SPSS package. The descriptive statistical parameters of frequency and percentages, including mean $(\bar{X})$ and standard deviation of central tendency will be used to present and analyze the field data. Particularly, the study will use the Spearman's Rank Correlation Analysis to 
test the stated Null hypotheses. The study also adopted the ordinary least square regression analysis to test the influence of Audit Evidence on Financial Statement Quality.

The reliability of instruments will be tested using Cronbach Alpha Coefficients, using the Statistical Package for Social Sciences (SPSS) Version 20.

\section{RESUlTS}

\section{A. Test of Hypothesis 1}

$\mathrm{Ho}_{1}$ : There is no significant relationship between Accounting Records and Reliability.

TABLE 1: CORRELATION BETWEEN ACCOUNTING RECORDS AND

\begin{tabular}{|c|c|c|c|c|}
\hline \multicolumn{5}{|c|}{ RELIABILITY } \\
\hline Type & Variables & Statistics & $\begin{array}{l}\text { Accounting } \\
\text { Records }\end{array}$ & Relevance \\
\hline \multirow{6}{*}{$\begin{array}{l}\text { Spearman's } \\
\text { rho }\end{array}$} & & Correlation & 1.000 & $.435 * *$ \\
\hline & $\begin{array}{l}\text { Accounting } \\
\text { Records }\end{array}$ & $\begin{array}{l}\text { Sig. (2- } \\
\text { tailed) }\end{array}$ & & .000 \\
\hline & \multirow{4}{*}{ Relevance } & $\mathrm{N}$ & 124 & 124 \\
\hline & & $\begin{array}{l}\text { Correlation } \\
\text { Coefficient }\end{array}$ & $.435 * *$ & 1.000 \\
\hline & & $\begin{array}{l}\text { Sig. (2- } \\
\text { tailed) }\end{array}$ & .000 & \\
\hline & & $\mathrm{N}$ & 124 & 124 \\
\hline
\end{tabular}

** Correlation is significant at the 0.01 level (2-tailed).

Table 1 shows that the spearman's correlation coefficient (r) $=0.435^{* * *}$. This value is moderate implying that a strong relationship exists between accounting records and reliability. Furthermore, the coefficient indicates a fairly moderate relationship between accounting records and the reliability of the financial statement quality. This means that improvement in reliability is linked with increase in accounting records.

The probability/ significant value $(\mathrm{PV})=0.000<0.05$ (level of significance) the researcher therefore rejects the null hypothesis and concludes that a significant relationship exists between accounting records and reliability.

\section{B. Test of Hypotheses 2}

$\mathrm{Ho}_{2}$ : Accounting Records and Relevance have no significant relationship.

TABLE 2: RELATIONSHIP BETWEEN ACCOUNTING RECORDS AND

\begin{tabular}{|c|c|c|c|c|}
\hline \multicolumn{5}{|c|}{ RELEVANCE } \\
\hline Type & Variables & Statistics & $\begin{array}{l}\text { Accounting } \\
\text { Records }\end{array}$ & Relevance \\
\hline \multirow{7}{*}{$\begin{array}{l}\text { Spearman's } \\
\text { rho }\end{array}$} & \multirow{4}{*}{$\begin{array}{l}\text { Accounting } \\
\text { Records }\end{array}$} & Correlation & & \\
\hline & & Coefficient & 1.000 & $.622 \cdots$ \\
\hline & & $\begin{array}{l}\text { Sig. (2- } \\
\text { tailed) }\end{array}$ & & .000 \\
\hline & & $\mathrm{N}$ & 124 & 124 \\
\hline & \multirow{3}{*}{ Relevance } & $\begin{array}{l}\text { Correlation } \\
\text { Coefficient }\end{array}$ & $.622 * *$ & 1.000 \\
\hline & & $\begin{array}{l}\text { Sig. (2- } \\
\text { tailed) }\end{array}$ & .000 & \\
\hline & & $\mathrm{N}$ & 124 & 124 \\
\hline
\end{tabular}

**Correlation is significant at the 0.01 level (2-tailed).

Table 2 shows that the Spearman's correlation coefficient $(r)=0.622^{* *}$, this value is high, implying that a strong relationship exists between accounting records and relevance. The value equally shows that to a very high extent, accounting records correlates with financial statement relevance. Positive relationship is indicated by the positive sign on the association between Accounting Records and Relevance. This means that improvement in relevance is linked with increase in accounting records.

The probability/significant value $(\mathrm{PV})=0.000<0.05$ (level of significance) the researcher consequently rejects the null hypothesis and concludes that a significant relationship exists between accounting records and relevance.

\section{Test of Hypotheses 3}

Ho3: Letter of Representation and Reliability has no significant relationship.

TABLE 3: RELATIONSHIP BETWEEN LETTER OF REPRESENTATION AND

\begin{tabular}{|c|c|c|c|c|}
\hline \multicolumn{5}{|c|}{ RELIABILITY } \\
\hline Type & Variables & Statistics & $\begin{array}{l}\text { Accounting } \\
\text { Records }\end{array}$ & Relevance \\
\hline \multirow[t]{6}{*}{$\begin{array}{c}\text { Spearman's } \\
\text { rho }\end{array}$} & \multirow{3}{*}{$\begin{array}{l}\text { Accounting } \\
\text { Records }\end{array}$} & $\begin{array}{l}\text { Correlation } \\
\text { Coefficient }\end{array}$ & 1.000 & $.620 * *$ \\
\hline & & $\begin{array}{l}\text { Sig. (2- } \\
\text { tailed) }\end{array}$ & & .000 \\
\hline & & $\mathrm{N}$ & 124 & 124 \\
\hline & \multirow{3}{*}{ Relevance } & $\begin{array}{l}\text { Correlation } \\
\text { Coefficient }\end{array}$ & $.620 * *$ & 1.000 \\
\hline & & $\begin{array}{l}\text { Sig. (2- } \\
\text { tailed) }\end{array}$ & .000 & \\
\hline & & $\mathrm{N}$ & 124 & 124 \\
\hline
\end{tabular}

Table 3 shows that the Spearman's correlation coefficient $(r)=0.620 * *$, this value is moderate, implying that a strong relationship exists between letter of representation and reliability. The correlation coefficient further indicates that to a very large extent, the exits a positive relationship between letter of representation as a dimension of audit evidence and the reliability of the financial statements. The positive sign is an indication of positive relations This means that improvement in reliability is linked with increase in letter of representation.

The probability/significant value $(\mathrm{PV})=0.000<0.05$ (level of significance) the researcher therefore rejects the null hypothesis and concludes that a significant relationship exists between letter of representation and reliability.

\section{Test of Hypotheses 4}

Ho4: There is no significant relationship between letter of representation and relevance

TABLE 4: RELATIONSHIP BETWEEN LETTER OF REPRESENTATION AND RELEVANCE

\begin{tabular}{ccccc}
\hline Type & Variables & Statistics & $\begin{array}{c}\text { Accounting } \\
\text { Records }\end{array}$ & Relevance \\
\hline $\begin{array}{c}\text { Spearman's } \\
\text { rho }\end{array}$ & $\begin{array}{c}\text { Correlation } \\
\text { Accounting } \\
\text { Records }\end{array}$ & $\begin{array}{c}\text { Coefficient } \\
\text { Sig. (2- } \\
\text { tailed) } \\
\text { N }\end{array}$ & 1.000 & $.873^{* *}$ \\
& Correlation \\
& Relevance & $\begin{array}{c}\text { Coefficient } \\
\text { Sig. (2- } \\
\text { tailed) } \\
\text { N }\end{array}$ & $.873^{* *}$ & 124 \\
& & .000 & 124 \\
& & 124 & 124 \\
\hline
\end{tabular}

**Correlation is significant at the 0.01 level (2-tailed).

Table 4 shows that the Spearman's correlation coefficient $(\mathrm{r})=0.873^{* *}$. This value is very high, implying that a very 
strong relationship exists between letter of representation and relevance. The value of the correlation coefficient further emphasizes the strength of the relationship between letter of representation and the relevance of the financial statement prepared by the companies. This means that improvement in relevance is linked with increase in letter of representation. Therefore, we reject the null hypotheses and accept the alternative.

\section{E. Discussion of Findings}

The study aimed at investigating the relationship between Audit Evidence and financial statement quality in Government owned parastatals in Rivers State, Nigeria. Accounting records and letter of representation were used as proxies for audit evidence, while relevancy and reliability were used to measure financial statement quality. The study tested four hypotheses. The result of hypotheses one indicated a very strong relationship between accounting records and reliability of financial statement quality. One interpretation of this finding is that an increase in the reliability of the financial statement will lead to an increase in accounting records. This finding gives credence to the work of Kiabel who explained that audit evidence as the factual and collateral materials which is capable of supporting various accounting actions which are carried out by any organization. It is also in compliance with the findings of Bribesh [1], [33].

The findings and a progress in reliable financial statement will tend to improve audit stressed that corporate financial statements should contain certain characteristics and attributes to be effective. Those characteristics and attributes will then enable the investors to rely on financial statements while taking financial decision evidence in the state ministries. The result of tested hypotheses two further indicated a positive relationship between accounting records and relevancy of financial statement quality. This means that an improvement in relevancy is linked with an improvement in accounting records of the ministries. This finding is in consonance with the views of Glover and Jardol [21], [22].

According to Obaidat and Elliot reliability quality of financial statement builds confidence of the investors [34]. However, this does not exempt the possibility of future distortive of the efficiency of the financial statement after reliability check.as expressed elsewhere in the study reliable financial statement is a pointer to the strength of the organization and an indicator the organization will compete well both in the present and the future. This finding further indicates that auditors will be more comfortable with financial report that shows a high degree of relevance; hence it boosts their audit functions.

The result of the tested hypotheses three indicated a moderate relationship between letter of representation and reliability of financial statement. In the views of Kaplan, it is expected that high audit evidence quality leads to high financial statement qualify which becomes an instrument for averting financial crisis and boosts stakeholder's confidence in financial statements.

According Janvrin, the auditors should assign greater persuasiveness to evidence from external parties than to evidence from internal parties. This will allow the external stake holders to appreciate the quality of financial statement prepared and be able to take decision based on the recommendation and the findings of the auditor's reports [24].

In line with the assertion of Petra, the findings of this study further indicate that audit team members placed more weight on information or evidence originating from other audit team members than information from client personnel [14]. This is an established fact as Anderson and Al-Angari further pointed out that auditors are sensitive to the objectivity of the source of evidence hence they are meticulous about taking decision base sources of evidence [39], [40]. The study further shows that Auditors consider evidence from a fellow auditor to have a higher standard of quality than evidence from the entity's management, because the fellow auditor is seen as more objective than client management.

Finally, the result of tested hypotheses for indicated a positive correlation between letter of representation and relevance of the financial statement. The implication of this observation is that an improvement in the relevancy of the financial statement there is the possibility of an improvement in the letter of representation as an audit evidence in the Rivers state owned ministries. This finding further buttresses the assertion of Lifeng, who investigated the impact of financial statement quality on investment costs, information uncertainty and agency and found that high - quality financial statements reduced investment and agency costs [39]. The study in question developed relevant hypotheses and the hypotheses was tested with relevant statistical tools. This gave enough credence to the outcome of such study. However, this present study observes a very strong relationship between audit evidence and financial statement credibility in Rivers State Ministries and Parastatals.

\section{CONCLUSION AND RECOMMENDATIONS}

The study concludes that audit evidence obtained by an auditor such as accounting records and letter of representation will enhance the quality of financial statements, and as a result improve greatly the relevance and reliability perception of accounting information users on financial statements of government owned companies in Rivers State. Secondly, the study confirms a progressive connection between audit evidence and financial statement quality, which is in accordance with the expectations of Kaplan that high audit evidence quality leads to high financial statement quality [32].

The study therefore recommends that:

1. Auditors should continuously insist on the submission of a letter of representation from management before the end of an audit, in order to enhance the relevance and reliability of financial statements they audit.

2. Auditors should exercise due diligence in the exercise of their duties, in order to maintain reliance and reliability in their capability and independence from users of Accounting information. 


\section{REFERENCES}

[1] Kiabel, Bariyima David. "Internal auditing and performance of government enterprises: a Nigerian study." Global Journal of Management and Business Research 12.6 (2012).

[2] Chen, Chih-Ying, Chan-Jane Lin, and Yu-Chen Lin. "Audit partner tenure, audit firm tenure, and discretionary accruals: Does long auditor tenure impair earnings quality?." Contemporary accounting research 25.2 (2008): 415-445.

[3] Agwor, Thankgod C. "The Normal Distribution of Financial Accounting Ratios as Indicators of Business Status." European Journal of Business and Management 6.35 (2014): 215-222.

[4] Sim, Jeffrey Wee Sing, and Khe Foon Hew. "The use of weblogs in higher education settings: A review of empirical research." Educational Research Review 5.2 (2010): 151-163.

[5] Eke, Surulola James. "No pay, no peace: political settlement and post-amnesty violence in the Niger Delta, Nigeria." Journal of Asian and African studies 50.6 (2015): 750-764.

[6] Olagunju, F. I., and R. Adeyemo. "Evaluation of the operational performance of the Nigerian agricultural credit cooperative and rural development bank (NACRDB) in South-Western Nigeria." International Journal of Agricultural Economics \& Rural Development 1.1 (2008): 1-15.

[7] Nyor, Terzungwe. "Financial reporting quality of nigeria firms Users' perception." International Journal of Business and Social Science 4.13 (2013): 273-79.

[8] Beest, F. Van, G. J. M. Braam, and Suzanne Boelens. "Quality of Financial Reporting: measuring qualitative characteristics." (2009).

[9] Kieso, Donald E., Jerry J. Weygandt, and Terry D. Warfield. Intermediate accounting IFRS. John Wiley \& Sons, 2020.

[10] Klai, Nesrine, and Abdelwahed Omri. "Corporate governance and financial reporting quality: The case of Tunisian firms." International business research 4.1 (2011): 158-166.

[11] Beekes, Wendy, Philip Brown, and Qiyu Zhang. "Corporate governance and the informativeness of disclosures in A ustralia: a re-examination." Accounting \& Finance 55.4 (2015): 931-963.

[12] Brown, Lawrence D., and Marcus L. Caylor. "Corporate governance and firm valuation." Journal of accounting and public policy 25.4 (2006): 409-434.

[13] Firth, Michael, Peter MY Fung, and Oliver M. Rui. "How ownership and corporate governance influence chief executive pay in China's listed firms." Journal of Business Research 60.7 (2007): 776-785.

[14] Petra, Steven T. "The effects of corporate governance on the in formativeness of earnings." Economics of Governance 8.2 (2007): 129-152.

[15] Klai, Nesrine, and Abdelwahed Omri. "Corporate governance and financial reporting quality: The case of Tunisian firms." International business research 4.1 (2011): 158-166.

[16] Bushman, Robert M., and Abbie J. Smith. "Financial accounting information and corporate governance." Journal of accounting and Economics 32.1-3 (2001): 237-333.

[17] Asegdew, Kirubel. "Determinants of financial reporting quality: Evidence from large manufacturing share companies of Addis Ababa." Addis Ababa University (2016).

[18] Faith, Patrick, and Ayman Hammad. "Financial transaction token with onboard power source." U.S. Patent Application No. 13/847,912.

[19] Agrawal, Anup, and Sahiba Chadha. "Corporate governance and accounting scandals." The Journal of Law and Economics 48.2 (2005): 371-406.

[20] Zakari, Mohamed. "Does Audit Evidence Type Effects on Quality of Auditor's Opinion?." International Conference" Financial Distress: Corporate Governance and Financial Reporting Issues", Rome (Italy) October. 2013.

[21] Glover, Troy D. "Social capital in the lived experiences of community gardeners." Leisure Sciences 26.2 (2004): 143-162.

[22] Martin, James Robert, and David Rose. Working with discourse: Meaning beyond the clause. Bloomsbury Publishing, 2003.

[23] Janvrin, Diane. "The Mitigating Effect of Internal Control Effectiveness on the Relationship between Source Objectivity, Evidence Set Size, and Evidence Persuasiveness." USA: University of Iowa, Working paper (2001)

[24] Kizirian, Timothy G., Brian W. Mayhew, and L. Dwight Sneathen Jr. "The impact of management integrity on audit planning and evidence." Auditing: A Journal of Practice \& Theory 24.2 (2005): 49-67.

[25] Asare, William Kweku. Slavery Reparations in Perspective. Trafford Publishing, 2002.

[26] White, Douglas W., et al. "Extra skeletal mesenchymal chondrosarcoma: case report." Clinical imaging 27.3 (2003): 187190.
[27] Hirst, D. Eric, Patrick E. Hopkins, and James M. Wahlen. "Fair values, income measurement, and bank analysts' risk and valuation judgments." The Accounting Review 79.2 (2004): 453-472.

[28] Goodwin, A., et al. "Renal chromophobe carcinomas with focal oncocytic-like morphology: Cytogenetic analysis of 5 cases." Laboratory Investigation. Vol. 86. 75 Varick Street, 9th Floor, New York, Ny 10013-1917 USA: Nature Publishing Group, 2006.

[29] Rosenbaum, Arthur Lewis. "China and Other Matters." China Review International 5.2 (1998): 537-541.

[30] Kaplan, Steven N., and Per Stromberg. "Leveraged buyouts and private equity." Journal of economic perspectives 23.1 (2009): 12146.

[31] Dawd, Issa, et al. "Corporate reporting and disclosures in the emerging capital market of Kuwait: the perceptions of users and preparers." International Journal of Disclosure and Governance 15.2 (2018): 61-72.

[32] Alrshah, Abdelfatah M. "An empirical analysis of audited financial statements reliability: Mediating role of auditor quality." International Journal of Finance and Accounting 4.3 (2015): 172 179.

[33] Sheri, Anaghir Saber, Et Al. "The Relationship Between Corporate Governance And Its Dimensions And Investment Efficiency On The Firms Accepted In Tehran Stock Exchange." (2017): 1-28.

[34] Aminu, Lawal, and S. U. Hassan. "Accounting conservatism and investment efficiency of listed Nigerian conglomerate firms." Scholedge International Journal of Business Policy \& Governance 3.11 (2016): 167-177.

[35] Sajjadi, M., et al. "The rate of knowledge and attitude toward psychoactive drugs and its abuse prevalence in Gonabad University students." The Horizon of Medical Sciences 15.2 (2009): 58-64.

[36] Noravesh, Iraj, and Seyed Ali Hosseini. "Corporate Disclosure Quality (consist of timeliness and reliability) and Earnings Management." Journal of Accounting and Auditing Review 16.2 (2009).

[37] Cooper-Thomas, Helena D., Annelies Van Vianen, and Neil Anderson. "Changes in person-organization fit: The impact of socialization tactics on perceived and actual P-O fit." European Journal of work and organizational psychology 13.1 (2004): 52-78.

[38] Al-Shatri, Eman H., and Hussam A. Al-Angari. "The reduction of audit fee level and its impacts on the quality of professional performance: an empirical study on audit firms in the Kingdom of Saudi Arabia." Economics and Administration 20.1 (2006). 